\title{
Securing Childhood : An Attempt To Regain The Lost World of Innocence from The Inhuman Practice of "Child Labor" In India.
}

\author{
KUNTAL MAJUMDER \\ Research Scholar of JJT University, Rajasthan.
}

and

\author{
PRIYA DAS \\ (Assistant Professor of English)Kabi Sukanta Mahavidyalaya, Bhadreswar(W.B)
}

\begin{abstract}
Child'- a symbol of innocence- is in a state of predicament due to the malpractice of 'child-labor' since ages. This paper tends to project the inherent problems related to the system of child-labor from both literally as well as literary point of view with reference to 'The Chimney Sweeper' poems by William Blake, and thereby suggests some possible remedies with a special emphasis on the physical and psychosocial development of the same.
\end{abstract}

Key Words: angel-infancy, non-traditional security threat, child-labor, chimney-sweeper, diabolical trinity, malnutrition, psychosocial, physical fitness, capitalist class, soft-security.

"O how I long to travel back

And tread again that ancient track!”

(Vaughan, 'The Retreat', 11. 21-22)

Henry Vaughan indeed takes us back to our golden days of childhood when we used to shine in our "Angelinfancy", a non-parallel phase of human life which renders memories sweet throughout our lifetime. Being the 'Golden Period', childhood days focuses on an ideal life - a pure and an innocent one when the infant indulges in all sorts of playful activities among Nature and becomes an indispensable part of it. This phase gives an individual an utmost pleasure spent in the imaginary world of fairy tales. During childhood days one feels safe and secured due to his/her close association with his/her parents, especially mother who plays the role of the 'Guardian Spirit' protecting her child from all sorts of predicaments.

Quite surprisingly, deviating from this normal trend emerges the concept of "child labor" system where usually the down-trodden class of the society is victimized. The innocent children who else would have been leading a normal healthy life are compelled to labor hard in various sectors and thereby earn their livelihood for themselves and their family. But how far is the practice of child labor justified? This paper focuses on the major problem of child-labor which has gained importance as a 'new-age' threat to the national security of different states. Hence it can be assumed as a 'non-traditional security threat' playing a pivotal role in reshaping the global architecture. This paper is an attempt to dig out a possible solution to this problem thereby trying to make an effort of 'securing childhood'. According to Mely Caballero-Anthony non-traditional security threats may be defined as "challenges to the survival and well being of people and states that arise primarily out of non-military sources, such as, climate change, cross-border environmental degradation and resource depletion, infectious diseases, natural disasters, irregular migration, food shortages, people smuggling, drug trafficking and other forms of transnational crime."

(Caballero-Anthony, 'An Introduction', Understanding Non-Traditional Security, Pp.1-4) Such issues usually affect both government institutions and civilian populations and can originate from various non-state human and natural causes and may be the upshots of certain acts by individual or social groups. Child labor is such a social evil, a threat that can be the cause of a great socio-economic and political upheaval in our country. One of the emerging threats of this $21^{\text {st }}$ century is the inhuman practice of child labor, a so called 'soft' security threat to our nation that fails to ensure the basic rights and happiness of children especially from that of the lower strata of the society- the poverty-stricken ones. It is a matter of great regret that millions of children are undergoing the worst forms of child labor which includes 'child slavery', 'child prostitution', 'child 
trafficking' etc. Children in this modern era are being callously exploited in almost every country. Child labor mainly refers to the employment of children in any work that deprives children of their childhood, interferes with their ability to attend regular school, and that is mentally, physically, socially or morally dangerous and harmful. According to ILO, child labor is best defined as work that deprives children of their childhood, their potential and their dignity which is harmful to both physical and mental development. It refers to work that is mentally, physically, socially or morally dangerous and harmful to children, whose schedule interferes with their ability to attend regular school and deprives them of a healthy childhood. [1]

Though child labor forms an intrinsic part of pre-industrial economies, the problems of child labor can be traced back in the $18^{\text {th }}$ century England when the socio- economic condition of the workers was deplorable due to the rapid growth of industrialization. Due to an abject poverty the parents often used to sell their children who were employed as domestic servants, chimney-sweepers, coal-miners etc. These children, especially the chimney-sweepers were highly in a state of demand as sweeping chimneys was quite a hazardous task for any elders; while small children could easily make an entrance inside the chimneys. These children in return of their hard labor were brutally treated and tortured by their masters. They were even compelled to shave their heads for the convenience of sweeping. Many children used to get choked during sweeping the chimney soot. Fortunately enough, due to a benevolent master-sweep named David Porter, a Parliamentary Act was passed in 1788 known as "Porter's Act" that limited the working hours of children and prohibited the employment of children below 8 yrs. William Blake, the Romantic poet of the period denounces the inhuman atrocities imposed upon children through his poem "The Chimney Sweeper" included in the collection- Songs of Innocence and Songs of Experience:

"When my mother died I was very young, And my father sold me while yet my tongue Could scarcely cry 'weep!' weep!' weep!' weep!' So your chimneys I sweep, and in soot I sleep."

(Blake, 'The Chimney Sweeper', Innocence, 11.1-4)

"Because I was happy upon the heath, And smil'd among the winter's snow, They clothed me in the clothes of death And taught me to sing the notes of woe."

(Blake, 'The Chimney Sweeper', Experience, 11.5-8)

In both the poems we find the inhuman tortures of the master class showering upon the infants who, though 'scarcely could cry weep', is forced to become expert in the art of sweeping the chimneys. It's indeed very painful to visualize the 'little black thing among the snow' in the Experience poem, whose parents seems to be 'quite satisfied' with 'it's profession' and hence worships the diabolical trinity for the well being of their 'earning child'. Ironically enough, on the contrary, the Innocence poem, gifts all the child-sweepers with a hope of eternal joy if they sincerely do their duty allotted to them by the master class - a Demigod to them.

During 1788, two-third of the workers in England and Scotland working in 143 water powered cotton mills were described as children. Many girl-children were enforced into prostitution. Charles Dickens, the great author, himself worked at the age of 12 in a blacking factory with his family in debtor's prison. According to Karl Marx, British industries "could but live by sucking blood, and children's blood too" (Neocleous, "The Political Economy', Pp. 668-684), and that U.S capital was financed by the "capitalized blood of children". [2] The issue of child labor is a major human rights issue and also a highly emotive one. It is a global phenomenon, which exists in almost all the countries of the world. "The concept and practice of child labor being economically unsound, psychologically wrong and socially disastrous has posed a big threat to peace and overall world development.” (Shandilya, 'Child Labour Eradication', p.83)

The present situation of India in this $21^{\text {st }}$ century cannot be claimed to have any better improvement regarding the system of child labor. The children belonging from the lower strata of the society are still victimized by the upper section of human-animals who make a slave out of them by employing them in different sectors as factory-workers, hotel boy, house-maid etc; while their parents equally encourage them in doing so. Child trafficking in this respect can be categorized under the system of child labor, as it's just the way of massive income by the traffickers. Some parents even debase themselves for money by employing their child as street-beggars who, they think, can earn money better by earning sympathy from the rich and well-to-do people. According to the estimation of UNICEF, India comprises of the highest number of laborers in the world under 14 years of age; while International Labour Organization estimates that agriculture at $60 \%$ is the largest employer of child labor in the world. In a report, UNICEF suggests, "Children's work needs to be seen as happening along a continuum, with destructive or exploitative work at one end and beneficial work - promoting 
or enhancing children's development without interfering with their schooling, recreation and rest - at the other. And between these two poles are vast areas of work that need not negatively affect a child's development." [3] The muscles of the average child, as per the demonstration of physiologists, attain a certain amount of strength and capacity for work only at the age of thirteen. Until that stage the muscular fibers contain a large percentage of water and hence are very tender and immature. According to George M. Kober, "As a consequence of this imperfect muscular development it is not surprising that we should find such a large percentage of children engaged in workshops, factories... develop lateral curvature of the spine and other muscular deformities, not to mention their general weakness and predisposition to rickets, tuberculosis and other pulmonary diseases." (Kober, 'The Physical and Physiological Effects of Child Labor', p. 27)

\section{MAJOR CAUSES OF CHILD LABOUR:}

The root cause of child labor is the socio-economic background which is the base of a society. Being an over-populated yet economically retarded country, India, comprises of a large number of people living below the poverty level. Consequently, beside their own toil, the parents engage their children in "the struggle for existence", who therefore becomes a part of domestic servitude or of different industrial belts. Another major cause can be said to be the lack of proper education and schools for the economically backward classes. In fact, India lacks a proper infrastructure for the schools which can provide free education to these children and also for those residing in rural areas or villages. While parents find it more convenient to engage their children, especially sons, in agricultural works who, therefore, can earn a daily wage for his family. Many boys with merit are even found to leave school at the mid-session in order to earn his livelihood by working at other states in different factories. Meritorious boys of rural areas or villages are often compelled by their parents to leave school forever with tearful eyes and had to leave for another state in search of work as their parents refuses to continue the payment of school fees due to their extreme poverty.

\section{CONSEQUENCES OF CHILD LABOUR: VISUALIZING THE LOST WORLD OF INNOCENCE:}

Child labor is like a canker to the society which, if not prohibited by law will soon produce hollowness at the core of the society; since children are the future of a nation. Due to this unnatural act the children becomes deprived of the very essence of childhood and suffers from an existential crisis. There is a saying: Child shows the Man as Morning shows the Day. So in order to enhance the progress of a civilization, a well-built intellectual citizen is needed, which on the contrary, depends on the upbringing of a child. But unfortunately the increase of the system of child labor is creating an adverse effect on our nation and our society. Innocence here gets unnaturally replaced by experience depriving the children of happiness and a playful healthy life of which they had every right. They are deprived of that education which else would have made a secured future for them. Besides, these poor children suffer from malnutrition and various diseases due to this sort of unhealthy life. The scope of 'child trafficking' increases in this respect ranging from industrial and domestic labor, to commercial sexual exploitation resulting sometimes in mortal diseases like AIDS leading to a premature and innocent death. Kids are more sensitive to dangerous insects and animal bites, but also to pesticides and accidents occurring due to tools and machineries which happen nearly as often as in the manufacturing sector. According to the Child Labor Public Education Project, working conditions that are safe and healthy for adults may prove otherwise in case of children because of their physical differences. Factors that may increase the health, safety, and developmental risk factors for children include: rapid skeletal growth, development of organs and tissues, greater risk of hearing loss, developing ability to assess risks, greater need for food and rest, higher chemical absorption rates, smaller size and lower heat tolerance. [4]

Another major effect of child labor is the psychosocial one. Children's social and educational development is profusely affected due to long hours of work in regular basis. The unconditional worst forms of child labor (e.g., slavery, soldiering, prostitution, drug trafficking) may have traumatic effects, including longer term health and socioeconomic effects. Unfortunately, girls become more victimized as they are often compelled to leave school at an early age and are entrusted with household activities either of their own or of the other. The alternative and most practiced way is to get them married in order to get rid of the 'extra burden' of the family. In most of the cases young girls working in different sorts of industrial sectors are found to be molested or even raped by the employers and are often sold to the red-light areas in return of a handsome amount of money. The parents in these cases are bound to be responsible for their misery as their poverty dominates their emotions and logicality.

In the respect of the above discussions we are reminded of the popular fairy tale often relished in our childhood - Cinderella which deals with the enforced slavery of the beautiful innocent girl by her stepmother and sisters, but ultimately finds a better future with her prince with the aid of her guardian angel. Unfortunately, no such princes or fairies exist in reality who can act as a savior to the poor children. In Blake's Chimney Sweeper from "Songs of Innocence", the child-speaker hopes for freedom as he dreams of an Angel 
who "had a bright key, / And he open'd the coffins and set them all free" (Blake, 'The Chimney Sweeper', Innocence, 11.13-14) . Ironically enough, what the innocent child fails to understand is the strategy of the capitalist class posing as an Angel who gives a false assurance of freedom to these unfortunates -

"So if all do their duty they need not fear harm". (ibid, 11. 24)

This is the ultimate truth usually taught to the labor-class children, i.e, their better future depends on their present capacity to labor hard and thereby earn money for themselves and their family. Thus one can visualize how the system of child labor threatens our country- it is a national curse, a by-product of socio-economic structure of the society. If not abolished by law, child labor will soon enhance the degradation of our society. The future of the Nation will be at stake leading to an increase of poverty level- since the capitalist class will utilize the opportunity of enslaving children in return of a meagre sum; and there will be a possibility of our country getting overpopulated as the slum-people will bear a tendency of utilizing their children in earning money for the family. Whatever may be it is the children who will be victimized in this class-war.

\section{POSSIBLE REMEDIES OF SECURING CHILDHOOD:}

- $\quad$ Since poverty is the root cause of all evils and social hazards, it needs to be uprooted from the society, and it can be done through the process of covering these children and their parents under various poverty alleviation and employment generation schemes formulated by the Government. If the guardians become capable of earning for the family, their children will never be 'victimized'.

- $\quad$ Besides, the poor children should be provided with a free education facility by launching special schools with the facilities of formal/non-formal education, different health activities to maintain their physical fitness, supplementary nutrition and regular health check ups.

- $\quad$ Adequate assistance and cooperation from various NGO's should be invited in this regard. Fortunately, many NGO's like "Bachpan Bachao Andolan", "ChildFund", "CARE India", etc. have been working to eradicate child labor in India. [5] In an interview, Ravi Shanker Kumar, a victim of 12-13 yrs shared his terrific experience of an enforced slavery in a carpet industry where he was beaten, tortured and kept in half-fed and half-clad, but was fortunately liberated in 2005 by the activists from "Bal Vikas Ashram". Later on he was provided a shelter and medical treatment at BVA besides counseling, literacy training and basic education. (Bales,Kevin and Trodd, 'Child Slavery'. Pp. 74-77)

Thus we can conclude that nothing is impossible if we have determination to achieve our goals. Hence the Government needs to emphasize on the mission of "securing childhood" by abolishing the system of 'child-labor' in every possible way, thereby providing a 'soft' security to these unfortunate ones and henceforth idealize our Country and our Nation.

$* * * * * * * * * * * * * * * * * * * * * * *$

\section{WORKS CITED}

1. Vaughan, Henry. "The Retreat". An Anthology: Poems, Plays and Prose. Eds. Board of Editors. The University of Burdwan: United Offset, 2005. 20-21. Print.

2. Caballero-Anthony, Mely, ed. An Introduction to Non-Traditional Security Studies: A Transnational Approach. SAGE, 2015. Print.

3. Blake, William. "The Chimney Sweeper from Songs of Innocence". University Anthology of Poems. Eds. Board of Editors. The University of Burdwan: United Offset, 2007.24. Print.

4. Blake, William. "The Chimney Sweeper from Songs of Experience". University Anthology of Poems. Eds. Board of Editors. The University of Burdwan: United Offset, 2007.25. Print.

5. Neocleous, Mark. "The Political Economy of the Dead: Marx's Vampires". History of Political Thought. Vol. 24, No.4 (2003): 668-684. Print.

6. Shandilya Kumar, Tapan and Nayan Kumar and Navin Kumar, eds. CHILD LABOUR ERADICATION. New Delhi: Elegant Printers. 2006. Print.

7. Kober M, George. "The Physical and Physiological Effects of Child Labor". The Annals of the American Academy of Political and Social Science. 27 (1906): 27-30. Web.5 July 2016.

8. Trodd Zoe, Bales and Kevin. "Child Slavery". To Plead Our Own Cause: Personal Stories by Today's Slaves. Ithaca: Cornell UP, 2008. 74-77. Print. 


\section{REFERENCES}

[1] What is Child Labour?" International Labour Organization. 2012. www.child labour in India Wikipedia, the free encyclopedia.htm. accessed on 27.06.2016. (Web).

[2] Karl Marx (1864). Inaugural Address of the International Working Men's Association (Speech). www. Child labour - Wikipedia, the free encyclopedia.htm. accessed on 27.06.2016. (Web)

[3] "Definitions: Child Protection".UNICEF.2012. www.child labour in India - Wikipedia, the free encyclopedia.htm. accessed on 02.07.2016. (Web).

[4] "Health Issues: Physical Differences between Children and Adults May Increase Children's Work-related Risks". Child Labor Public Education Project. www.continuetolearn.uoiwa.edu.htm. accessed on 05.07.2016. (Web).

[5] "Child Labour in India". www.child labour in India - Wikipedia, the freeencyclopedia.htm. accessed on 03.07.2016. (Web).

$* * * * * * * * * * * * * * * * * * * * * * * * * *$ 